УДК 378 (477.63)

\author{
О. В. Федоненко, Т. С. Шарамок
}

Дніпропетровський національний університет ім. Олеся Гончара

\title{
ВИДАТНІ ДІЯЧІ ГІДРОБІОЛОГІЧНОЇ НАУКИ
}

Розглянуто історію кафедри іхтіології, гідробіології та екології Дніпропетровського національного університету. Наведено біографію засновника кафедри - Д. О. Свіренка та його послідовників - Г. Б. Мельникова, І. П. Лубянова, С. П. Федія та інших. Вказано основні напрямки роботи кафедри іхтіології, гідробіології та екології на теперішній час.

\author{
O. V. Fedonenko, T. S. Sharamok \\ Oles' Gonchar Dnipropetrovsk National University
}

\section{OUTSTANDING MEN OF HYDROBIOLOGICAL SCIENCE}

The history of the Ichthyology, Hydrobiology and Ecology Department of Dnipropetrovs'k National University is under review. Biographies of the founder of the Department - D. O. Svirenko and his followers - G. B. Mel'nikov, I. P. Lubyanov, S. P. Fediy and others are presented. Main areas of the work of the Ichthyology, Hydrobiology and Ecology Department at the moment are given.

\section{Ветуп}

Кафедра іхтіології, гідробіології та екології Дніпропетровського університету заснована у 1928 році. У витоків кафедри стояв видатний учений європейського масштабу, доктор біологічних наук, член-кореспондент АН України Дмитро Онисифорович Свіренко.

На сьогодні недостатньо наукових праць присвячено вивченню наукової діяльності світочів гідробіологічної науки. Мета роботи - дослідити біографію засновників кафедри іхтіології, гідробіології та екології ДНУ та напрямки їх наукової діяльності.

\section{Результати досліджень Д. О. Свіренка}

Д. О. Свіренко народився 24 жовтня 1888 року у с. Мерчик Харківської губернії у селянській родині. У 1907 році у Харкові закінчив Реальне училище після початкового. Із 1908-го навчався у Харківському університеті на біологічному відділенні фізико-математичного факультету, де почав вивчати альгологію під науковим керівництвом професора В. М. Арнольді. Закінчив вищий навчальний заклад із відзнакою. Перші наукові роботи молодого вченого привернули до себе увагу, тому у 1918 році його запросили на

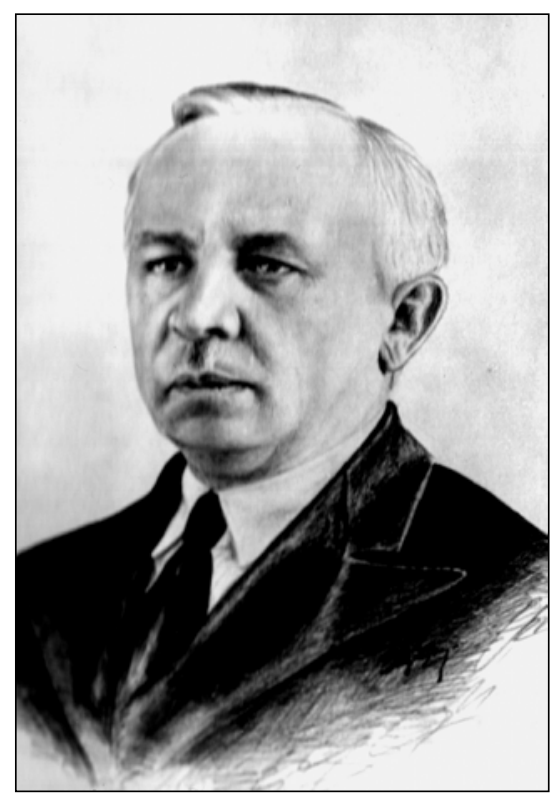
місце асистента професора М. В. Цингера, а через

(C) О. В. Федоненко, Т. С. Шарамок, 2008 
фесора М. В. Цингера, а через рік він став приват-доцентом Харківського університету. У 1920 році Д. О. Свіренко переїздить до Катеринослава (нині - м. Дніпропетровськ), де працює доцентом кафедри ботаніки Катеринославського університету. У цьому ж році він стає професором, а $з$ 1921-го завідує кафедрою ботаніки.

У 1923 році Д. О. Свіренка запрошують до Одеського університету на посаду професора кафедри ботаніки та за сумісництвом директором Одеського ботанічного саду, де він працює до 1927 року. У цей період науковець бере участь у Міжнародному гідробіологічному конгресі у Римі, де стає лауреатом, захищає докторську дисертацію та веде активну роботу з молодими вченими. Одночасно з виконанням індивідуальних робіт Д. О. Свіренко організовує колективні комплексні гідробіологічні експедиції, у яких беруть участь співробітники Одеського ботанічного саду та Дніпропетровської біологічної станції АН УРСР. У 1925-1926 роках проводяться експедиції на нижню течію Південного Бугу. У 1927-му відбулася перша комплексна експедиція з вивчення порожистої частини Дніпра. У цьому ж році Д. О. Свіренко повертається до Дніпропетровська та очолює кафедру в Інституті народної освіти. Цей переїзд був пов'язаний із його бажанням зайнятися вивченням Дніпра та взяти участь в організації Дніпропетровської гідробіологічної станції. У 1928 році конкурсна комісія Управління науки затвердила Дмитра Онисифоровича іï директором.

Основні наукові роботи Д. О. Свіренка присвячені систематиці водоростей і топології річок. Він описав нові види нижчих рослин, упорядкувавши систематику деяких їх груп. Видані у 1912-1928 роках альгологічні праці Д. О. Свіренка «Определитель эвгленовых водорослей Украины» та «Микрофлора стоячих водоемов» висунули їх автора до числа визнаних спеціалістів у даній галузі міжнародного значення.

Значну увагу у своїх наукових дослідженнях Дмитро Онисифорович Свіренко приділяв альгофлорі ставків. Він ставив перед собою завдання прослідкувати, як відбувається заселення новоутвореної водойми водоростями, яким чином відбивається на складі альгофлори старіння водойми, пов'язане з їі заростанням і заболочуванням. Ці питання майже не були розглянуті в ті часи ні у вітчизняній, ні в іноземній літератуpi. Як об'єкт дослідження Д. О. Свіренко обрав тип ставків, що приймають воду з різних джерел, у тому числі й дощову, яка не приносить водорості з інших водойм. Він вів спостереження за такими ставками поблизу Харкова, унаслідок чого дослідив склад і розподіл водоростей, їх сезонну динаміку заселення ставків.

У 1933 році у Дніпропетровському державному університеті створено кафедру нижчих рослин і гідробіології, яку очолив професор Д. О. Свіренко. На базі кафедри і гідробіологічної станції Д. О. Свіренко створив велику аспірантуру. У цей період розпочате комплексне дослідження закономірностей формування гідробіологічного режиму Дніпровського (нині - Запорізького) водосховища. За заслуги в організації та проведенні комплексних досліджень Дніпровського водосховища у 1934 році Д. О. Свіренка призначають членом-кореспондентом АН УРСР. У 1938-му під редакцією науковця почала виходити 5-томна монографія «Дніпровське водосховище».

Під час війни Д. О. Свіренко працював в Оренбурзькому педагогічному інституті. Тут він вивчав гідробіологію ріки Урал. Незадовго до смерті (у 1944 р.) вчений опублікував свою останню монографію «Лекарственные растения».

Д. О. Свіренко має понад 50 наукових робіт, надрукованих у наукових журналах, у тому числі й іноземних. Крім того, багато популярних статей у журналах і газетах. Сформовані ним іхтіологічна та гідробіологічна школи отримали своє продовження завдяки його учням. 


\section{Роботи учнів Д. О. Свіренка}

Серед перших аспірантів професора Д. О. Свіренка був Петро Петрович Ширшов (1905-1953рр.), який став дійсним членом АН СРСР, а в 1937-1938 рр. входив до складу легендарної Папанінської четвірки, досліджував гідробіологічний режим Карського моря та моря Лаптєвих. За мужність і героїзм, проявлені під час дрейфу станції «Північний полюс», П. П. Ширшову присвоєно звання Героя Радянського Союзу.

У 1929 році аспірантом Д. О. Свіренка став Петро Олексійович Журавель (19011976). Основним напрямком його наукової діяльності було комплексне гідробіологічне та рибогосподарське дослідження природних і штучних водойм степової зони України та Криму, збагачення прісних рибопромислових водойм природними ресурсами живлення риб, кормова база рибної промисловості, санітарна та технічна гідробіологія [4]. Під його керівництвом проводились широкомасштабні роботи з акліматизації у водоймах різних кліматичних зон СРСР водних безхребетних лиманно-каспійського типу, які є високопоживним кормом для риб. Автор понад 100 праць у галузі гідробіології.

У цьому ж році аспірантом професора Д. О. Свіренка стає випускник Дніпропетровського університету Георгій Борисович Мельников (1904 $1973)$ - видатний учений-гідробіолог, педагог вищої школи, який багато років свого життя присвятив розвитку Дніпропетровського державного університету. У 1936 році. Г. Б. Мельников захистив кандидатську, а у 1940-му - докторську дисертацію, яка узагальнила дослідження закономірностей зміни зоопланктону р. Дніпро у зв'язку з утворенням Запорізького водосховища. У 1934-1938 роках Г. Б. Мельников працював доцентом Дніпропетровського сільськогосподарського інституту та одночасно - директором Інституту гідробіології ДДУ. У 1938-1941 роках був завідувачем кафедри дарвінізму та деканом біологічного факультету ДДУ. У роки Великої Вітчизняної війни - заступником директора та професором Бійського, а потім - Волгоградського педінститутів.

Наприкінці війни кафедра нижчих рослин і гідробіології дДУ була центром підготовки спеціалістів у галузі гідробіології. У 1944 році керівництво кафедрою, яка стала іменуватись кафедрою гідробіології, прийняв професор Г. Б. Мельников. У зазначеному році була відновлена аспірантура при кафедрі гідробіології ДДУ. Наслідки війни диктували необхідність широкого розгортання підготовки спеціалістів-гідробіологів для народного господарства та організації комплексного вивчення водойм степової зони Української РСР. Відновний період після Великої Вітчизняної війни (1946-1950) висунув на порядок денний наукову розробку впливу різноманітних джерел забруднення на гідрофлору та гідрофауну водойм, науковий аналіз комплексного використання ставків степової зони України. Такі дослідження велись під керівництвом Г. Б. Мельникова.

Iз 1951 по 1964 рік Г. Б. Мельников був ректором Дніпропетровського державного університету. Із 1960-го професор Г. Б. Мельников став піонером нової галузі науки космічної біології. Співробітники лабораторії космічної біології на чолі з Г. Б. Мельниковим розробили оригінальні методики вивчення дії екстремальних факторів на пове- 
дінку водних організмів (тварин) і теоретичних основ гідроекологічних систем забезпечення життя космонавтів в умовах тривалого космічного польоту. Ці розробки використані при проектуванні орбітальних космічних станцій «Салют» і «Мир».

До наукових інтересів професора Г. Б. Мельникова входило велике коло питань. Насамперед це вивчення зоопланктону Дніпровського водосховища, його приток (кандидатська і докторська дисертації та монографія «Зоопланктон Запорізького водосховища» були написані на основі цього матеріалу).

Під керівництвом Г. Б. Мельникова проводилися гідробіологічні та рибогосподарські дослідження порожистої частини Дніпра (до відновлення Дніпрогесу), дослідження відновленого водосховища і водойм степової зони України. Роботи «Донные иловые отложения Днепровского водохранилища» (1948) та «Формирование фауны Днепровского водохранилища после восстановления плотины Днепрогэса» (1950) присвячені саме цим питанням. Г. Б. Мельников брав активну участь в Іхтіологічній комісії СРСР, Науковій раді Українського товариства охорони природи, був членом редколегії «Гідробіологічного журналу», вів насичене громадське життя. Г. Б. Мельников автор понад 170 наукових робіт, багато з яких авторитетні й у наш час [5-10]. За заслуги перед вітчизняною наукою Г. Б. Мельников нагороджений двома орденами та трьома медалями, мав Почесне звання «Заслужений діяч науки УРСР».

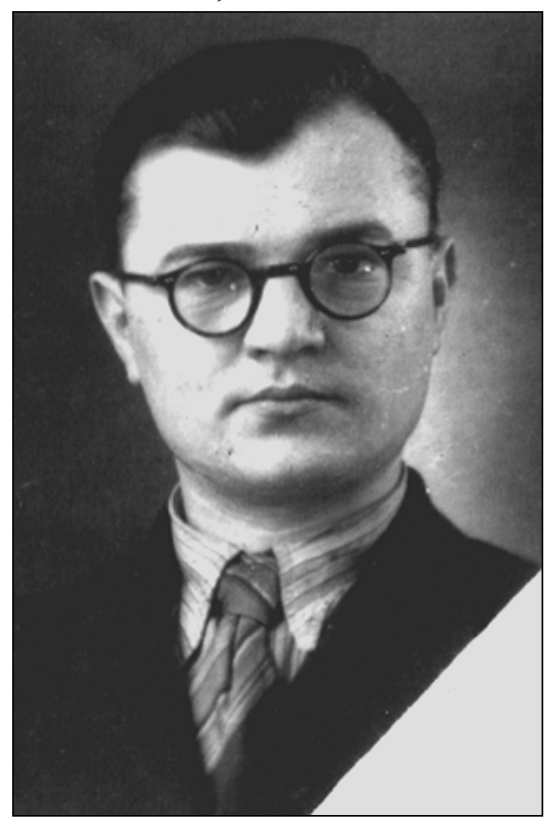

Великий внесок у гідробіологічну науку зробив Іван Павлович Лубянов (1921-1975). Вирішення «проблеми великого Дніпра», починаючи 3 1950-го, потребувало поглиблених досліджень нижнього Дніпра (у зв'язку з будівництвом Каховської гідроелектростанціï) і середнього Дніпра (у зв'язку з будівництвом Дніпродзержинської гідроелектростанціi). За матеріалами цих досліджень захищено ряд кандидатських дисертацій, у тому числі й І. П. Лубянова. Із 1954 по 1959 рік І. П. Лубянов працював на посаді завідувача лабораторії гідробіології Інституту гідробіології та за сумісництвом (1953-1964) - завідувачем відділу гідробіології та біофізики. Із 1965 по 1967 рік обіймав посаду декана біологічного факультету ДДУ. Із квітня 1967-го I. П. Лубянов призначений директором НДІ гідробіології ДДУ. Працюючи на цій посаді, він захистив (1972) докторську дисертацію «Биологические основы защиты гидросооружений от фауны биоценозов обрастания Днепродзержинского и Запорожского водохранилищ (проблемы технической гидробиологии)». Перебуваючи на посаді директора НДІ, організував лабораторії біофізики та технічної гідробіології, очолив розробку нових методик у гідробіологічних дослідженнях на основі використання приладів із напівпровідниками. Напрямами наукової роботи І. П. Лубянова були санітарна та технічна гідробіологія, проблеми розробки та впровадження у виробництво засобів захисту гідроспоруд і систем промислового водопостачання від біообростань [11]. Важливий напрям наукових інтересів І. П. Лубянова - прісноводна радіоекологія, у розробці якої він приділяв особливу увагу питанням екології водних тварин. Розробив спеціальний курс із радіоекології для студентів. У 1963 році І. П. Лубянов обраний секретарем Ученої ради ДДУ, був членом наукових рад АН СРСР за спеціальностями «Радіобіологія» та «Гідробіологія, іхтіоло- 
гія та використання біологічних ресурсів водойм». Автор понад 130 наукових робіт. Результати досліджень проблем технічної гідробіології багаторазово доповідалися та обговорювалися на всесоюзних конференціях та з'їздах ВГБТ АН СРСР. І. П. Лубянов був членом бюро-секції біології Будинку вчених, заступником голови бюро Дніпропетровського відділення ВГБТ АН СРСР. На посаді завідувача кафедри іхтіології, гідробіології та екології біолого-екологічного факультету він працював з 1974 по 1975 рік.

Із 1958-го на кафедрі гідробіології дДУ та НДІ гідробіології під керівництвом Сергія Петровича Федія (1914-1981) вирішувались проблеми регіональної рибогосподарської токсикології, встановлювались критерії токсичності водного середовища для гідробіонтів, у тому числі риб.

У 1973 році С. П. Федій захистив докторську дисертацію, а з 1976 по 1978-й завідував відділом гідробіології та іхтіології НДІ біології Дніпропетровського державного університету. Із 1978 року і до кінця життя працював на посаді професораконсультанта кафедри гідробіології.

Співробітники Інституту гідробіології та кафедри гідробіології під його керівництвом досліджували іхтіофауну Нижнього Дніпра та брали участь у розробці рибогосподарського освоєння Каховського водосховища.

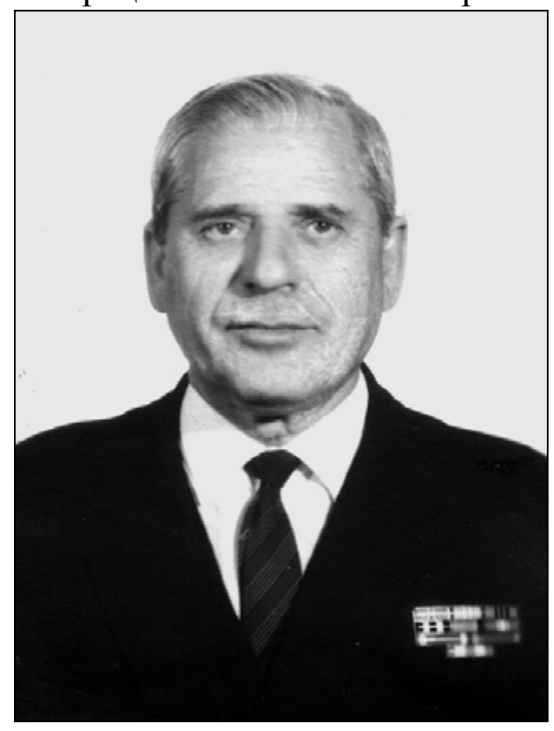

Тривалий час С. П. Федій був експертом із проблем охорони водних ресурсів від промислового та побутового забруднення у Раді Економічної Взаємодопомоги країн Варшавського договору. Автор 67 наукових робіт, найцікавіші з яких - «Влияние промышленного загрязнения на условия обитания рыб в водохранилищах Днепровского каскада» (1962), «О теории и практике улучшения санитарно-гидробиологического режима водоемов УССР» (1965).

\section{Сучасні дослідження}

Нині співробітники кафедри продовжують вести наукові дослідження за напрямами, розпочатими керівниками кафедри іхтіології, гідробіології та екології. Основними напрямами сучасної дослідницької роботи на кафедрі є вивчення проблем збереження та збільшення промислово цінних видів риб рибогосподарських водойм в умовах антропогенного навантаження; дослідження особливостей розвитку безхребетнихгідробіонтів, особливостей штучного відтворення та вирощування основних об'єктів аквакультури України, стану організму риб природних і штучних водойм, умови та чинники виникнення захворювань риб і засоби боротьби з ними, вивчення особливостей накопичення токсичних речовин в організмі риб та міграції токсикантів у гідроекосистемах; дослідження радіоекологічної ситуації у водоймах басейну Дніпра та наслідки іiі впливу на гідробіонтів.

\section{Бібліографічні посилання}

1. Професори Дніпропетровського національного університету / Під ред. М. В. Полякова. Д.: Вид-во Дніпропетровського університету, 2003. - 320 с.

2. Радзимовский Д. А. Дмитрий Онисифорович Свиренко // Гидробиол. журн. - 1969. - Т. 5 , № 2. - С. 91-93. 
3. Дворецкий А. И. Светлые лучи биолого-экологического факультета / А. И. Дворецкий, Ф. П. Рябов // Екологічний вісник України. - 1993. - № 4 (9). - С. 1.

4. Журавель П. А. Некоторые замечания об изменениях фауны в порожистой части р. Днепра в связи с Днепростроем // Природа. - 1934. - № 8. - С. 50-56.

5. Мельников Г. Б. Ихтиофауна озера Ленина (Днепровского водохранилища) после его восстановления // Вестн. Днепропетр. НИИ гидробиол. - 1955. - Т. 11. - С. 163-188.

6. Мельников Г. Б. Состав ихтиофауны и пути рыбохозяйственного освоения озера Ленина и малых водохранилищ // Вопр. ихтиологии. - 1955. - Вып. 3. - С. 42-48.

7. Мельников Г. Б. Некоторые общие закономерности формирования ихтиофауны в водохранилищах Днепровского каскада / Г. Б. Мельников, Л. Д. Беляев, В. Л. Булахов // Биол. основы реконструкции, рационал. использ. и охраны фауны юж. зоны европ. части СССР. Матер. зоолог. совещ. - Кишинев, 1965. - С. 213-220.

8. Мельников Г. Б. К вопросу о направленном формировании фауны рыб озера имени Ленина / Г. Б. Мельников, В. Л. Булахов // Тр. Зональн. совещ. по типологии и биол. обоснованию рыбохоз. использования внутренних (пресновод.) водоемов южной зоны СССР. - Кишинев: Штиинца, 1962. - С. 320-323.

9. Мельников Г. Б. Характеристика распределения основных промысловых рыб в Ленинском водохранилище на Днепре в условиях каскада / Г. Б. Мельников, В. Л. Булахов, С. Н. Тарасенко // Биол. основы управл. повед. рыб в связи с применением рыбозащ. и рыбопропуск. сооруж. Матер. симпоз. - М.: Наука, 1971. - С. 85-88.

10. Реконструкция ихтиофауны и кормовой базы для рыб в водоёмах юга Украины / Г. Б. Мельников, А. М. Чаплина, И. П. Лубянов и др. // Изв. ГосНИОРХ. - 1964. - Т. 57. - С. 130-136.

11. Лубянов И. П. Изменения в составе макро- и микрозообентоса Днепровского водохранилища после зарегулирования стока среднего Днепра / И. П. Лубянов, А. М. Бузакова, Ю. К. Гайдаш // Гидробиологический режим Днепра в условиях зарегулированного стока. К.: Наукова думка, 1967. - С. 167-175.

Надійшла до редколегії 28.06.2008 